\title{
THE INTERNET PRESS IN THE POLISH LAW
}

\author{
ANNA GARCZEWSKA ${ }^{1}$
}

Kazimierz Wielki University (Poland)

\begin{abstract}
The aim of the paper is to define the legal basis of registration of the on-line press with the use of the analytical method. The press in the Polish law is defined as a periodical publication transmitted by print, audio or audio and video, or published on the Internet, or have both printed / audio / video and on-line issues. The registration is mandatory only for daily newspapers and magazines, whether they are traditional or on-line publications. Lack of registration can happen due to the court or due to the publisher, the latter being a petty offence. Registration requirements for the on-line press are constant conflict issues in contemporary Poland as it is the subject of wide interpretation. The Press Law was enacted thirty years ago and has been slowly amended, though the lack of unified interpretation makes it difficult for the people engaged in on-line activity to know, understand, and predict the legal frame of their work. KEYWORDS: Press Law, blog, newspaper, magazine, on line press, e-press.
\end{abstract}

JEL CODES: K15, K40

DOI:

\section{Introduction}

The Internet is a complex structure that can be understood as a means of communication or a network of computers. Here, in this article, the Internet itself is not treated as a web of computers or the press per se, but as a medium and a form of communication. It is difficult to define it as it can be stationary or mobile, local or worldwide, free or paid, interactive or passive, etc. It offers many ways of communication: individual (e.g., e-mail, teleconference, on-line banking), group (e.g., chatrooms, P2P, on-demand streaming), or mass (webpages, podcasts, videocasts, blogs). Since the Internet delivers a cyberspace for social life, it also provides the space for existence of the press.

Problem. There is a definition of the press in the Polish law, however, social and technical changes make it less obvious with the times. There are problems with interpretation of: the word "periodically", the substance of a publication, and the form of a publication. One of the most controversial issue is the registering of the press. Registration is mandatory for daily newspapers and magazines. The problem is how to assess whether certain on-line activity constitutes the press in general and needs no registration or should it be considered as a daily newspaper or a magazine with mandatory registration. Are the people engaged in on-line activity journalists? Are they treated as the press? Should they register? Are they allowed to register? The questions arise: Where is the line between "the on-line press" and "the non-press Internet activity" and how to decide whether registration is necessary? It is not clear whether bloggers should register as the press, because neither provisions nor judiciary make it clear for the Internet users. In literature, some authors deem the registration necessary for a publication to be called the press while others see this requirement as a postcommunism legacy. There are legal consequences either way.

\footnotetext{
Anna Garczewska - PhD., assisstant professor, Chair of Journalism, New Media and Social Communication, Kazimierz Wielki University, Bydgoszcz, Poland

Scientific interests: media law, IP law, common law, Law-and-Film

E-mail: garczewska@ukw.edu.pl
} 
The aim of the paper. This paper aims to describe provisions and their interpretations in court rulings as well as in the literature connected with registration of the on-line press. It also aims at deciding whether certain aspects of the on-line activity should be considered as the press, therefore, should be registered as a daily newspaper or a magazine.

Research methods: analysis and interpretation of legal provisions, analysis of judiciary opinions and verdicts, analysis of literature.

\section{1. "The press": definition}

There is a legal definition of the press in Article 7, section 2, point 1 of the act of January 26, 1984 - The Press Law, J. L. No. 5, item 24 - amended (Ustawa z dnia 26 stycznia 1984 roku - Prawo prasowe (Dz. U. Nr 5, poz. 24 ze zm.)) and referred hereinafter as "the Press Law": the press shall be considered periodical publications that do not constitute limitative and homogeneous entirety, are published at least once a year and bear a permanent title or a name, a number and a date, including, but not limited to, daily newspapers and magazines, newswires, telex messages, bulletins, radio and television broadcasts, film chronicles; the press shall also be any means of the mass media, existing and emerging in the course of technological advancement, including broadcasting stations and PA systems that distribute periodical publications via print, video, audio, or any other broadcasting means; the press shall also cover teams of people and individuals engaging in the journalistic activity. This definition presents three dimensions of the press, namely: subjective (publication), institutional (the mass media) and objective (people).

The Press Law is considered to be referring to the Internet in describing the means of the mass media as existing and emerging in the course of technological advancement. There was no Internet in Poland when the act was enacted, yet the lawmakers seem to have been aware of the possible advancement of new technologies and haven't made any precise restrictions of the form of communication. Hence, it is possible for on-line publications to be treated as the press.

The act provides a definition of the two main forms of periodical publications: daily newspapers and magazines. Under Article 7, section 2, point 2 of the Press Law, a daily shall be a general-information periodical print or a message transmitted via audio or via audio and video that is published more than once a week. Moreover, in accordance with Article 7, section 2, point 3 of the Press Law, a magazine shall be a periodical print published once a week or less, but not less than once a year; this provision should be applied accordingly to audio messages, and audio and video other than described in point 2 of Article 7, section 2. In both cases registration is mandatory. Article 20 of the Press Law states that publishing a daily newspaper or a magazine requires registration in a regional court of venue for the publisher's registered office. Registration of a daily newspaper or a magazine should expire if it has not been published within a year after acquiring the publishing rights for an unspecified period, or after a year of hiatus in publishing, unless editorial office applied to keep registration active.

\section{The press and the Internet - Supreme Court rulings}

The Press Law does not provide a definition for all possible forms of communication that would be defined as the press, that, on the one hand, allows new forms of the media to be called the press, however, on the other hand, it causes assessment problems related with the registration requirements. On-line publications do not fit easily into old definitions. In 2007, the Supreme Court (Postanowienie Sądu Najwyższego z 26 lipca 2007 r., IV KK 174/07, uzasadnienie opublikowane w Biuletynie Prawa Karnego nr 15 z 2007 r., s. 35-37) stated that daily newspapers and magazines are still considered as the press whilst published on-line, whether it is their on-line issue, or it is the Internet standalone material. However, an electronic daily or a magazine should be registered, otherwise the publisher commits an offence without doing a proper registration in the regional court. The ruling of 2007 was immensely criticized in the legal literature and among the Internet users. Lech Gardocki explained that the Supreme Court in 2007 did not state that running a webpage means 
publishing the press, but the webpage can be used to publish a daily newspaper or a magazine, and then the publisher is obliged to register (Gardocki, 2007).

In 2010, the Supreme Court (Postanowienie Sądu Najwyższego z 15 grudnia 2010 r., III KK 250/10 uzasadnienie opublikowane w Biuletynie Prawa Karnego nr 4 z 2011 r., s. 23-28) decided that the Internet itself is not the press, though publications using the Internet as a medium can be called the press and it is the frequency of publication that determines whether it is a daily or a magazine. Therefore, webpages, homepages, or correspondence kept via e-mail do not need to be registered. The Internet is treated as a paper in printed publications, therefore the paper itself is not registered, while the pages printed specifically to be treated as an issue of a publication can be registered as a newspaper or a magazine. The same analogy can be used referring to the Internet.

\section{Registration requirements for the on-line press}

Article 20 of the Press Law states that publishing a daily newspaper or a magazine requires registration in the regional court of venue for the publisher's registered office, hereinafter referred to as "the registration body". Section 2 of the abovementioned article says that registration application should include: the title of a daily newspaper or a magazine, information on the registered office, and the exact address of the editorial office; personal data of the editor-in-chief; publisher's data, registered office, and the exact address; the frequency of publishing of a daily newspaper or a magazine. The registration ruling is a summary disposition, the court should substantiate it only upon motion.

In 2007, the Supreme Court (op. cit.) pointed that necessary elements of the on-line publication are: the name and address of the publisher, and the name and surname of the editor-in-chief. In the Supreme Court's opinion, ISSN number is not mandatory.

It costs 40 PLN to register the press publication under Article 23, point 1 of the act of July 28, 2005, of the court costs in civil cases, J.L. of 2010, No. 90, item 594, as amended (Ustawa z dnia 28 lipca 2005 r. o kosztach sądowych w sprawach cywilnych, t.j. Dz.U. z 2010 r. Nr 90, poz. 594 ze zm.).

One of the reasons of the registration is protection of already existing titles. In 2007 and 2010, the Supreme Court stated (op. cit.) that registration ensures that the press title is strictly connected with one specific publisher and the press publication, thus it protects the customer, allowing him/her to receive a product he/ she expects to buy.

In 2010, the Supreme Court also described what should be understood as the press title: it includes description of a daily newspaper or a magazine as a publishing unit, and a specific name of the publication that becomes its designator. The court does not investigate the right to the title, the main aim is to provide a possibility to officially register it. The registration does not validate illegal titles as the publisher is entitled to the legal action against subjects infringing their right to the press title. The press title's function is to identify the product of the publisher, to communicate, to differentiate it from other publishing products. The press title can be the object of legal transactions. It can be protected by both copyright (as a work) and the industrial property law (as a trademark).

\section{The Press Law, judiciary and life}

Taking under consideration the Press Law and the Supreme Court Ruling one can say that the medium of transmission does not matter when it comes to a decision whether a publication is the press. What matters is the form of publication (e.g., impressum) and the substance (the press materials). Generally, one can say that there can be three forms of the press publications: traditional (printed, audio, audio and video), traditional having its Internet issue (printed, audio, audio and video plus on-line) and the Internet only (on-line). Some scientists do not believe that there is the web press, e.g., Joanna Kulesza holds the opinion that it is not possible for on-line publications to be the press as the Internet is not transmitting print (Kulesza, 2010: 205). However, most of researchers and judiciary agrees that there is the on-line press, and it is possible for e-pu- 
blications to be called the press under the Press Law (Sobczak, 2014: 34; Lis, 2016: 100). The problem arises when it comes to decide whether a specific title should be registered and/or the people writing and placing information can be called journalists and/or publishers.

The press is a periodical publication via print, audio, or audio and video. Registration is mandatory only for daily newspapers and magazines; other forms of the press do not need to be registered. The problem arises in assessing whether on-line activity constitutes the press in general and do not need to be registered or it can be/should be considered as a daily newspaper or a magazine. Are the people, engaged in on-line periodical activity and presenting their views, opinions or information, journalists? Can they be treated as the press? Should they register? Do they need and want to register? Are they allowed to register? The question is: Where is the line between "the on-line press" and "the non-press Internet activity", and how to decide that registration is necessary?

Registration of the press title is conducted in the court procedure based on Article 20 of the Press Law. The on-line press can be registered as a daily newspaper or a magazine if it fulfils all statutory requirements of the press definition (Article 7, section 2), i.e.: on-line information is published periodically more than once a week (a daily) or less than once a week, yet at least once a year (a magazine) and bear a permanent title or a name, a number and a date. To register the on-line press the editor must submit an application as described in the abovementioned Article 20 of the Press Law.

Thus, it seems that the on-line radio or television must be registered, while personal opinions, diaries, family chronicles do not fall into that category. It is not so obvious, however, when it comes to classification of the on-line activity.

On the one hand, in 2007, the Supreme Court stated that webpages do not need to be registered, on the other hand, some on-line services of the courts inform that registration of the webpages that transmit audio or audio and video is mandatory if it fulfils the Press Law requirements. The reason is the literal interpretation of Article 7, section 2, point 2 of the Press Law under which a daily is a general-information periodical print or a message transmitted via audio or via audio and video, that is published more than once a week. Hence, systematic audio information published on-line should be registered as the press. One can find specific information and applications in the BIP services of the Polish courts, e.g.: the regional court in Warsaw placed information about the application procedure with specification that "registration of webpages and the Internet portals is proceeded if they fulfil the requirements of Article 7, section 2, point 2 of the Press Law, i.e., are transmitted on the Internet via audio or audio and video" (Regional Court in Warsaw, 2017).

Janusz Barta and Ryszard Markiewicz imply that publishing periodically means publishing consecutively new packets of information, whereas those volumes should appear in similar intervals and should belong to the same print, audio or audio-visual publication. Although they believe that updating a webpage without publishing new information in a certain distinct digital volume cannot be treated as publishing periodically (Barta, Markiewicz, 2005: 205). Therefore, webpages should not be registered as the press, unless they publish information in distinct updated periodically volumes.

Maciej Siwicki (Siwicki, 2014) believes that the on-line press excludes webpages with general information only, i.e., address of the company or short characteristic of the conducted business; folder-pages with detailed information presenting services or products and vortals with homogenous and limitative entirety. He argues that vortals presenting periodical information for the mass reader regardless of their topic (current news, general information, professional or highly specified data, religious, entertainment, etc.) can be called the press.

Piotr Waglowski wrote that a website can be called the press if it is not the homogeneous closed entirety, is periodical, has a name / title, a number and a date, e.g., newsletter falls into that category. A podcast or a videocast should be registered if it is periodical, and has a name/title, a number and a date, though the lack of formal requirements implies the lack of mandatory registration. In his opinion, the sound is the determinant of registration - if there is a sound, or a sound and a picture the registration is mandatory (VaGla, 2007).

A. Adamski observes that due to development of the on-line press the definition of the press should be modified considering the fact that information is acquired and processed by the indefinite number of viewers (Adamski, 2010). 
Some decisions of the court, e.g., that a title is the press and should be registered, are a side effect of the civil action. People who seek evaluation of their conflict in court argue whether on-line activity cause infringement of their rights (their name, image, copyright, defamation). The courts decide whether the infringement took place, i.e., they assess if a person publishing information is a journalist, whether the on-line information is the press material and publishing activity is the press activity, and consequently if it should be registered.

There is a difference between the possibility of registration for people who want to register and mandatory registration for those who do not wish to be treated as the press. One might say: ignorantia iuris nocet, however, unclear provisions, lack of clear and stable interpretations, fluctuating opinions in doctrine do not place bloggers into the "unaware" category. Provisions are published and known, it is not a problem, however, the implication of them, putting into action or even understanding certain aspects, is a problem. There seems to be more and more pressure on blogs to be registered. One of the most controversial issues connected with the Press Law in contemporary Poland is assessment of the bloggers' activity. Their actions can have legal consequences such as in the case of public officials: in 2011, the policeman writing a blog and using information acquired at work was found guilty of misconduct and was given a warning of insufficient aptitude for service (ruling of the Supreme Administrative Court of June 9, 2011, I OSK 1056/11 (Wyrok NSA z 9 czerwca 2011 r., sygn. I OSK 1056/11)) (VaGla, 2012); and a school principal was dismissed for publishing information on the conflict between him and the teachers (ruling of the Higher Court of Białystok of June 2, 2011, II SA/Bk 386/11 (Wyrok WSA w Białymstoku z 2 czerwca 2011 roku, sygn. II SA/Bk 386/11)) (VaGla, 2012).

Since 2007, the Polish judiciary holds the opinion that the web press should be registered if it can be defined as a daily newspaper or a magazine under the Press Law, i.e., if it is periodical and systematic. In 2013, the Appellate Court in Łódź (Postanowienie Sądu Apelacyjnego w Łodzi z dnia 18 stycznia 2013 r., sygn. akt I ACa 1032/12, OSA/Łdz. 2013 Nr. 3, poz. 23) stated that the blog is not homogenous enough in form to exclude it form the press definition. If the publisher decides that the Internet is going to be the only medium of communication, the aim of the blogger is communicating information, and materials are prepared in the editorial manner, then the press definition can be applied, and registration is mandatory. The court seems to underline three aspects of the web activity: the sole form of communication via the Internet, communication of information, and the editorial process; they imply if the publisher wants to publish the on-line press. The amount and changeability of the web activity is difficult to assess and control, provisions are unclear, and it seems that the courts deal with random cases rather than with most common problems. Basically, one can argue that most of the judiciary support the attitude that if the activity on the Internet is periodical (once a week, once a year), systematic, formal (title, name, number, date), presents information, not opinions, and the Internet is the only form of transmission, it should be registered.

Blogs can be the press, and many of them are, but the Press Law demands registration only if the press is a daily or a magazine, i.e., the information is published systematically - more than once a week or less than once a week, yet at least once a year. If we add the information requirement, then a lot of bloggers will not fit into the mandatory registration category. The judiciary tends to examine the aim of publications before deciding whether a person should register them as the press. The problem is the court ruling, usually issued post-factum, i.e., not at the time of the registration process, but during the conflict solving process. That's a bit late for the people engaged in on-line activity, as many of them do it without a precise decision about the exact aim of their publications beforehand, furthermore, the material they publish changes and evolves. The on-line press is developing rapidly, there are one-person editorial offices where the owner, the publisher, the editor-in-chief, and the journalist is the same and only person (Taczkowska, 2012: 152). It is more complex than the traditional press as the Internet offers more tools and usage of some of them cannot be easily classified. The risk is that they publish the way they believe, and it is in compliance with the law, but a few years later interpretation of the law changes and their behaviour might be treated as infringement. It is not impossible as the courts implement the provisions ad casum. 
The registered blog is treated as the press under the Press Law, therefore the blogger should be treated as a journalist, the published material is the press material, etc. Consequences of the registration are inter alia: protection of the press title, the press privileges such as the right to confidentiality and anonymity of the blogger, the blogger has a duty to publish truthful and rigid material, the blogger is obliged to authorization of the quoted information, as well as the publisher has a duty of publishing the correction.

\section{Lack of registration}

There are two possible situations when publishing takes place without registration: let's call the first one "due to the court" and the other "due to the publisher".

Lack of registration due to the court can happen when the registration body fails to adjudicate the registration application within 30 days of its submission. In such cases, a daily newspaper or a magazine can be published - Article 20 section 4 . Such actions should not be considered as a petty offence, since it was the court, not the publisher, that has not managed to fulfil a statutory requirement and register a periodical.

Lack of registration due to the publisher, however, is treated differently. Publishing without registration is a petty offence - a court can fine the publisher under Article 45 of the Press Law. This means that if the publisher fails to submit the application to register it can be deemed a petty offence and may be punished with a fine of up to 5000 PLN (Article $24 \S 1$ of the code of petty offences (Ustawa $z$ dnia 20 maja $1971 \mathrm{r}$. - Kodeks wykroczeń, t.j. Dz.U. z 2015 r. poz. 1094 ze zm.). There were 9 people convicted in the years 2002-2016 (Ministerstwo Sprawiedliwości, 2014).

\section{Conclusions}

Activity of the Polish press is regulated by the act enacted 30 years ago. This act provided a legal frame for editors and journalists, though it was also a tool of control of the press by the communist regime. On the one hand, it has given the press privileges such as confidentiality, on the other hand, it has demanded registration of the title, so the censorship could control and handle it. The act has been amended numerous times, most recently in November 2017. Provisions and interpretation thereof cause emotional debates, as well as every proposal of change.

The Press Law provisions do not refer to the Internet, although it is quite unanimously accepted that the definition of new techniques of transmission is so universal that can be applied to the Internet. Under Article 7 of the abovementioned act, the press is a periodical publication via print, audio, or audio and video. Registration is mandatory only for daily newspapers and magazines; other forms of the press do not need to be registered. The problem arises in assessing whether on-line activity constitutes the press in general and do not need to be registered or should be considered a daily newspaper or a magazine, thus registration is necessary.

Most of the cases tried by the Polish courts are those related to registration, civil cases and penal cases. There seems to be more and more pressure to register blogs.

On-line activity offers more possibilities rather than the traditional press, therefore it is more difficult to define whether a certain publication falls into a certain category. Since the court do not weights in merits of the journal at the registration, then the application could be reviewed by any office, e.g., like the Patent Office. The Press Law act was written in a different reality, its amendments are useful but superficial, as the act does not cover many areas of the new press activity leaving many issues problematic in practice and at best unclear. It is very difficult to operate on the unclear legal basis, especially for young people who do not remember the world with no Internet or no freedom, and for whom those two qualities are inseparable. They create a new world, digital one, but with a real core as their backbone is the reality they live in and should not be suppressed by the old bureaucracy. I believe the provisions should be clear, but not enumerative, precise but not concise, giving space to operate not to interpret. Hoping for a better legal future. 


\title{
References
}

Adamski, A. (2010). Strony internetowe a wymóg rejestracji prasy. Państwo i Prawo, No. 2, p. 30-43.

Barta, J., Markiewicz, R. (2005). Postęp techniczny w mediach. In: J. Barta, R. Markiewicz, A .Matlak. Prawo mediów. Warszawa.

Chajewska, A., Cichońska, A., Matusiak, I., Orlik, K. (2017). Prawo prasowe. Postępowania sadowe w sprawach prasowych. Komentarz. Warszawa.

Gardocki, L. (2007). Strona www.sn.pl nie jest dziennikiem ani czasopismem. 06.09.2007.

Kulesza, J. (2010). Ius Internet. Między prawem a etyka. Warszawa.

Lis, W. (2016). Prasa internetowa. Proces migracji mediów do cyberprzestrzeni. Rocznik Bibliologiczno-Prasoznawczy, Vol. 8/9, 2016, p. 97-108.

Ministerstwo Sprawiedliwości. (2017). Skazania prawomocne - dorośli - w latach 2002-2016. Available at: https:// isws.ms.gov.pl/pl/baza-statystyczna/opracowania-wieloletnie/download,2853,40.html [Accessed: November 23, 2017].

Postanowienie Sądu Apelacyjnego w Lodzi z dnia 18 stycznia 2013 r., sygn. akt I ACa 1032/12, OSA/tdz. (2013). Nr. 3, poz. 23.

Postanowienie Sądu Najwyższego z 26 lipca 2007 r., IV KK 174/07, uzasadnienie opublikowane w Biuletynie Prawa Karnego nr 15 z 2007 r., s. 35-37.

Postanowienie Sądu Najwyższego z dnia 15 grudnia 2010 r., sygn. akt III KK 250/10, KZS 2011 Nr. 4, poz. 16.

Regional Court in Warsaw. (2017). Available at: http://bip.warszawa.so.gov.pl/artykuly/232/rejestr-dziennikow-i-czasopism.

Rzeczpospolita. Available at: http://www.rp.pl/artykul/57716-Strona-www-sn-pl-nie-jest-dziennikiem-ani-czasopismem.html.

Siwicki, M. (2014). Pojęcie prasy i przestępstwa prasowego. Prokuratura i Prawo, Vol. 1, p. 85-106.

Sobczak, J. (2000). Prawo prasowe. Warszawa.

Sobczak, J. (2014). Prawne uwarunkowania funkcjonowania mediów. Część 1. Studia medioznawcze, Vol. 1 (56), p. $25-44$.

Taczkowska, J. (2012). Zawód dziennikarza w Polsce. Między misja a posłannictwem. Bydgoszcz.

Ustawa z dnia 20 maja 1971 r. - Kodeks wykroczeń, t.j. Dz.U. z 2015 r. poz. 1094 ze zm.

Ustawa z dnia 26 stycznia 1984 roku - Prawo prasowe, t.j. Dz. U. Nr. 5, poz. 24 ze zm.

Ustawa z dnia 28 lipca 2005 r. o kosztach sądowych w sprawach cywilnych, t.j. Dz.U. z 2010 r. Nr 90, poz. 594 ze zm.

Ustawa z dnia 4 lutego 1994 r. o prawie autorskim i prawach pokrewnych, t.j. Dz. U. z 2017 r. poz. 880 ze zm.

VaGla. (2007). Podcast $i$ videocast wykorzystują dźwięk czyli dalsze dywagacje nt. pojęć ,,prasa” ,dziennik” $i$,,czasopismo". 26.03.2007. Available at: http://prawo.vagla.pl/node/7175.

VaGla. (2012). Odpowiedzialność dyscyplinarna za prywatny "blog” funkcjonariusza Policji. 25.03.2012. Available at: http://prawo.vagla.pl/node/9719.

Wyrok NSA z 9 czerwca 2011 r., sygn. I OSK 1056/11.

Wyrok WSA w Białymstoku z 2 czerwca 2011 roku, sygn. II SA/Bk 386/11.

\section{INTERNETINÉ SPAUDA LENKIJOS TEISÉJE}

\author{
ANNA GARCZEWSKA \\ Kazimierz Wielki universitetas (Lenkija)
}

\section{Santrauka}

Šio straipsnio pagrindinis tikslas - apibrèžti internetinio spaudos registravimo teisinị pagrindą taikant analizès metodą. Problema, kaip įvertinti, ar internetinè veikla (kaip tinklaraščiai, straipsniai) gali būti vadinami spauda ir ar jiems būtina registracija, kaip yra su realiais „popieriniais“ leidiniais, ar ji turètų būti laikoma dienraščiu ar žurnalu, kuriame privaloma registracija. Ar žmones, dalyvaujančius internetinejje vei- 
kloje, turime vadinti žurnalistais, kuriems tokiu atveju taikomi tam tikri reikalavimai? Ar internetinè veikla laikoma spauda? Ar tinklaraštininkai turètų užsiregistruoti? Ar jie gali registruotis? Kyla klausimas, kur yra riba tarp ,internetinès spaudos“ ir tiesiog „,internete pateikiamos informacijos“, ir kaip nuspręsti, ar būtina registracija? Neaišku, ar tinklaraštininkai turètų užsiregistruoti kaip spaudos atstovai, nes nei nuostatos, nei teismai nenurodo interneto vartotojų atsakomybès.

Vienų mokslininkų nuomone, publikacija, kur bebūtų paskelbta, turi būti vadinama spauda, kitų nuomone, toks reikalavimas yra postkomunistinis palikimas. Lenkijos teisès aktuose nurodyta, kad spauda apibrèžiama kaip periodinis leidinys, perduodamas spausdintine, garso ar garso ir vaizdo medžiaga, arba paskelbtas internete, arba pateiktas tiek atspausdintų, tiek garso / vaizdo įrašų ir internetinių leidinių pavidalu. Žiniasklaidos įstatyme yra nuorodų ị internetą, apibūdinant žiniasklaidos priemones, kurios bus pateikiamos pažangiomis technologijomis. Tačiau Lenkijoje, kai aktas buvo priimtas, dar nebuvo interneto, nors, regis, įstatymų leidèjai žinojo apie galimą naujų technologijų pažangą, tačiau nebuvo tiksliai suformuluoti ir reglamentuoti bendravimo būdai internetu. Registracija privaloma tik dienraščiams ir žurnalams, nesvarbu, tai yra tradiciniai (spausdintiniai) ar internetiniai leidiniai. Kitiems leidiniams, kaip tinklaraščiams ar pateiktiems vaizdo / garso forma nėra jokio reglamentavimo. Nors pagal žiniasklaidos įstatymą, internetiniai leidiniai gali būti laikomi spauda.

Internetinès spaudos registracijos reikalavimai šiuolaikinejje Lenkijoje nuolat aptarinejjami, yra prieštaringų nuomonių, nes suinteresuotieji asmenys juos interpretuoja, kaip nori. Spaudos ịstatymas buvo priimtas prieš trisdešimt metų ir pamažu keičiamas. Kadangi trūko bendro išaiškinimo, internete veikiantiems žmonèms sunku suprasti ir numatyti jų darbo teisinị pagrindą.

PAGRINDINIAI ŽODŽIAI: spaudos ìstatymas, tinklaraštis, laikraštis, žurnalas, internetinè spauda, elektroniné spauda.

JEL KLASIFIKACIJA: K15, K40

Received: 2018.01.02

Revised:2018.01.29

Accepted: 2018.02.16 